\title{
Overcoming the Deficiency of Singular Detection by Antibody Arrays in Cancer Biomarker Discovery
}

Weidong Jiang ${ }^{1}$ and Ruo-Pan Huang ${ }^{1,2 *}$

${ }^{1}$ RayBiotech Inc, Norcross, GA 30092, USA

${ }^{2}$ RayBiotech Inc, Guangzhou, 510600, China

\begin{abstract}
Since cancer is a heterogeneous disease, it is unlikely that a single biomarker will detect all cancers of a particular organ with high specificity and sensitivity. Thus, detection of expression of multiple proteins is essential to unraveling the mechanisms and effects of carcinogenesis. Antibody arrays have been developed to meet this growing demand. The ability to simultaneously measure the expression profiling of multi-protein markers will provide a powerful platform for identification of new cancer biomarkers. In this review, we will discuss the planar format of antibody array technology, its suitability and challenges for cancer biomarker discovery, and examples of its applications for biomarker discovery and validation in a wide variety of human cancers.
\end{abstract}

Keywords: Antibody array; Proteomics; Cancer; Biomarkers

\section{Cancer Biomarkers Overview}

\section{Cancer biology}

Cancer is a complex, multi-factorial disease driven by both genetic and epigenetic factors. It leads to uncontrolled cellular growth, manifested by altered signaling pathways including cell cycle deregulation, inhibition of apoptosis, blockage of differentiation, enhancement of angiogenesis, invasion and metastasis. The crosstalk among these pathways will greatly influence biological behavior of oncogenesis, i.e., its initiation, promotion, progression, metastasis and recurrence. Often these changes include perturbations in tumor microenvironment and resulting local inflammation could lead to protein profile alterations in sera and plasma. Therefore, evaluating changes in cellular protein profiling and identifying cancer-associated proteins between cancer and non-cancer patient samples could provide useful information. The goal for cancer proteomics is to identify cancerspecific biomarkers for specific cancer types, specific cancer stages, or responses for particular treatments.

\section{Biomarker}

Biomarker, according to the official definition by NIH, is "a characteristic that is objectively measured and evaluated as an indicator of normal biological processes, pathogenic processes, or pharmacologic responses to a therapeutic intervention" [1]. Therefore, a biomarker is the end result of a bioassay, a laboratory technique for processing biological material from humans, expressed quantitatively or categorically. The measurement outcome of a biomarker could be binary, categorical, quantitative or something more complicated [2]. For clinical application, biomarkers may be divided into the following categories: A) screening markers, which could be used to distinguish healthy states from asymptomatic early stage of a cancer; B) prognostic markers, which could be used to predict the likely course of cancer and thus aggressiveness of the treatment; C) efficacy markers, which could be used to monitor the efficacy of drug treatment.

\section{The need of multi-marker panel for cancer biology}

Cancer is a heterogeneous disease; it is unlikely that a single biomarker will detect all cancer of a particular organ with high specificity and sensitivity. For example, prostate-specific antigen (PSA) is a biomarker for prostate cancer with high sensitivity yet low specificity. CA125 is a biomarker for ovarian cancer with high sensitivity and low specificity [3]. It is widely agreed that high specificity is the key performance issue for a successful cancer screening marker. Due to the prevalence rate of many cancer types, even a small false positive rate in a screening biomarker assay will translate into a large number of unnecessary costly diagnostic procedures and stress. Therefore, multimarker assays, rather than single marker assays, must be used for potential cancer screening with high sensitivity and specificity. During the early stages of cancer, when the changes in certain biomarkers are probably marginal, multiple biomarkers will have compounded power to distinguish between cancer and normal compared with any single biomarker.

\section{Cancer biomarker discovery phases}

Pepe et al. proposed 5-phase guidelines for development of biomarkers for early cancer detection [1]. The 5 phases are as follows,

a. Phase 1: preclinical exploratory studies with aims to identify leads to potential cancer biomarkers;

b. Phase 2: clinical assay development for a clinical disease with aims to establish performance efficacy of clinical biomarker assays in distinguishing cancer subjects from cancer-free subjects;

c. Phase 3: retrospective longitudinal repository studies with aims to evaluate the capacity of the biomarkers to detect preclinical disease;

d. Phase 4: prospective screening studies with aims to determine the operating characteristics of the biomarker-based screening test in a relevant population;

*Corresponding author: Ruo-Pan Huang, RayBiotech Inc, 3607 Parkway Lane Suite 200, Norcross, GA 30092, USA, E-mail: rhuang@raybiotech.com

Received October 21, 2011; Accepted August 27, 2012; Published August 30 2012

Citation: Jiang W, Huang RP (2012) Overcoming the Deficiency of Singular Detection by Antibody Arrays in Cancer Biomarker Discovery. J Mol Biomark Diagn 3:132. doi:10.4172/2155-9929.1000132

Copyright: ( 2012 Jiang W, et al. This is an open-access article distributed under the terms of the Creative Commons Attribution License, which permits unrestricted use, distribution, and reproduction in any medium, provided the original author and source are credited 
e. Phase 5: cancer control studies with aims to estimate the reduction in cancer mortality afforded by the screening test.

In biotech industry practice, these 5-phase guidelines for cancer biomarker discovery could be shortened to 3 phases, a. discovery phase, b. validation phase, c. product development phase [2].

\section{Antibody Array Technology as a Tool for Cancer Biomarker Discovery}

\section{Overview}

With the completion of human genome sequence, the next step is to understand the biological function of the proteins encoded by the genes. Protein microarray technology has drawn great attention for its high-throughput, flexibility and cost effectiveness. Though current protein microarray technology is still facing significant challenges, it has been used in a wide range of applications for protein expression and function, including protein expression profiling, protein-protein interaction screening, protein modification discovery and autoantibody characterization. In this overview, the current perspectives of protein microarray technology are reviewed.

Protein microarray technology consists of a large number of regularly arranged discrete spots of capture reagents, which transferred on a solid support using spotting robots. The development of protein microarrays requires each of the following steps: production and characterization of capture reagents, printing of capture reagents onto appropriate solid support (substrates), sample incubation, detection of bound molecules and data analysis.

Antibody array technology has emerged as a promising platform for cancer biomarker discovery due to its incomparable advantages, i.e., adaptability to high-throughput, multiplex format, quantitative readout, microliter-volume sample consumption, speed and costeffectiveness [4-11]. Among different approaches for protein detection using antibody arrays, 3 platforms have been applied: sandwich-based, label-based and competition-based antibody arrays.

Sandwich-based antibody arrays are the most common. Hundreds of publications have documented the suitability of sandwich-based antibody arrays to detect differential protein expression patterns using various body fluid types, including serum, plasma, urine, sputum, saliva, tears, prostatic fluid and other biological fluids $[4,5]$. Improvements in protein array technology, such as the development of arrays containing hundreds to thousands of proteins, simplified protocols, and highsensitivity assays have made this platform very attractive for biomarker discovery. Protein array content comes in many forms. We have developed an innovative biomarker platform utilizing our high density arrays for screening and quantitative arrays for validation and clinical application.

This review will focus solely on planar format antibody arrays, their technological advances, and application for cancer biomarker discovery. Since antibody array technology has been growing continuously, this review does not intend to cover the published literature exhaustively, but will focus on the most important publications on cancer-related applications.

\section{Advantages}

Compared to the current protein analysis technology, protein microarray technology has the following advantages: high-throughput, flexibility, cost effectiveness, reduced sample consumption, and fast turn-around-time. Unlike DNA microarrays which detect DNA and
mRNA, protein microarrays detect protein. Almost all the work within cells is performed by proteins; protein levels are regulated not only at transcriptional level, but translational and post-translational levels as well. Therefore, protein arrays reflect cell functions more accurately compared to DNA arrays. Under some circumstances, protein microarray technology provides a better choice than genome-based approaches [4-11].

\section{Platforms}

Antibody arrays have been designed to simultaneously detect multiple protein levels in an array format. The design principle of antibody arrays is usually based on either a sandwich-based immunoassay or a direct-labeling approach. The sandwich format requires a pair of antibodies: one immobilized (capture antibody) and one in solution (detection antibody); this method has the advantages of excellent specificity and sensitivity. However, the combinations and the number of antibody pairs in each array are limited by occasional crossreactivity between detection antibodies. For this reason, the optimal number of antibody pairs that can be included in one array is within 100. If larger numbers of targets are desired, they could be arranged in a series of array panels and be analyzed sequentially with biological samples [12]. In the direct-labeling approach, fluorescence or biotin labeling of target proteins is employed in lieu of introducing detection antibodies [13]. Because the cross-reactivity is eliminated in the label-based format, array densities can be scaled up to a theoretically unlimited size, thus overcoming the marker-limitation issues in sandwich-based approach. Both the label-based method [14] and the sandwich-based method [15] have proven valuable in the discovery of disease biomarkers.

In addition to these popular platforms of antibody arrays, several new platforms have been developed. The rolling circle amplification (RCA)-linked antibody array has been used to enhance detection sensitivity [16]. In the RCA system, an oligonucleotide primer is covalently attached to a detection antibody. The bound DNAconjugated antibody is then hybridized to a circular DNA molecule, resulting in a DNA molecule with multiple copies of DNA sequence that remains attached to the antibody. The amplified DNA can then be detected by hybridization with fluorescence-labeled complementary oligonucleotide probes or integration of labeled-nucleotide during rolling process. The intensity of the signals can thus be greatly enhanced. However, due to the difficulty of the assay procedure, low reproducibility of the amplification step, and high cost, the RCA method has not been widely applied in academics or industries.

More recently, there is a novel array design principle on the horizon: the competition-based array (or EIA-based array, Jiang et al, Unpublished data). In this format, a mixture of labeled peptide antigens is added to the sample, producing a signal inversely proportional to the amount of endogenous antigen present. Like the label-based array format, the EIA-based array is a robust multiplex assay and shows great promise for targeting proteins without a suitable antibody pair or that are too small to allow the simultaneous binding of two antibodies (unpublished observations). Moreover, the EIA-based array has been demonstrated to be fully quantitative, referencing a predetermined mixture of unlabeled peptide standards (unpublished observations) (Figure 1).

\section{Planar support}

Several different platforms of antibody arrays have been developed. The solid supports used in the fabrication of planar antibody arrays 


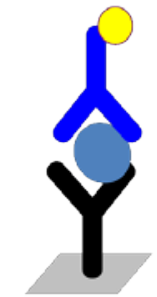

A. Sandwich Method

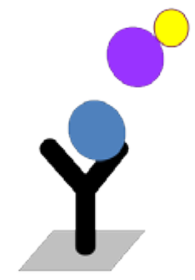

B. Competitive Method

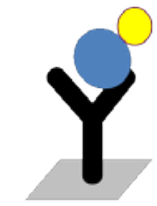

C. Direct-lable Method

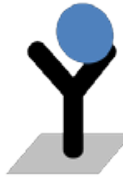

D. Label-free Method
Figure 1: Different platforms for planar-form of antibody arrays. (A) The sandwich method requires an immobilized capture antibody and a labeled, insolution detection antibody. (B) The competitive method relies on competitive binding between the analyte and a labeled antigen. (C) The direct-label method requires the label being attached to the analyte itself. (D). The label-free method relies on an inherent property of the analyte (such as mass per unit area or surface plasmon resonance) to produce a signal.

include glass slides, 96-well plates, and nitrocellulose membranes. Nitrocellulose and chemically activated or polymer-coated glass microscope slides are the most commonly used supports. Glass slidebased arrays provide the advantage of miniaturization; the surface can accommodate minute amounts of capture antibody (spots $<200 \mu \mathrm{m}$ in diameter), thereby reducing the array size [17]. Smaller array size then allows multiple arrays to be printed on one chip, making them suitable for high throughput analysis [18]. Each $25 \times 75 \mathrm{~mm}$ glass chip can accommodate thousands of antibody spots using current contact or non-contact array printers. Membrane-based arrays typically have chemiluminescent readouts, making them a favorable, low cost option that is easily adaptable to existing Western blot detection systems.

\section{Detection}

Fluorescence is by far the most commonly used readout system [19], offering high signal stability and wide dynamic signal range. Fluorescence detection is also utilized in bead-based suspension arrays, an alternate array platform involving the attachment of capture antibodies to microspheres coupled to combinations of fluorescent dyes. The various combinations of fluors confer unique identities to the beads, which can be sorted and quantified by flow cytometry. The beadbased array is a flexible format allowing the creation of customized bead mixtures. The drawback of this technique is that the capture antibodies, being attached to beads in solution, can potentially interact with one another or even clump together. This disadvantage is not inherent to planar arrays.

Recently, label-free signal detection technologies have seen a surge in interest [20-22]. Instead of attaching common labels to proteins (biotin, enzymes, or fluorescent tags), label-free methods rely on the detection of an inherent property of the target molecule. Label-free detection technologies include surface plasmon resonance (SPR), quartz crystal microbalance (QCM), microcantilevers, and quantum dots, just to name a few [21]. First and foremost, these techniques seek to address the possible artifacts (masking of epitopes or alteration of functionality) that may be introduced by chemical modification of the protein. Some label-free methods also have unique advantages; SPR for instance, not only measures concentration of a target protein, but also the strength of binding interactions, allowing the calculation of dissociation constants. SPR-based detection has been applied to antibody array chips for the detection of cancer-related cytokines in human serum [21] (Table 1).

\section{Challenges}

Although protein microarray technology has received great attention and enthusiasm in academia and industry, protein microarrays present significant challenges and technical hurdles not faced by DNA microarrays. The first serious obstacle is the extremely low abundance of many biologically important proteins. Unlike DNA and RNA which can be amplified by powerful PCR techniques, there is no protein amplification technique available. The second obstacle is the vast range of analyte concentrations to be detected. Protein concentrations exist over a broad dynamic range (by up to a factor of $10^{10}$ ), but no detection system can currently detect more than $10^{4}$ fold difference. The third challenge is the delicate nature of proteins. Compared to DNA and RNA, proteins are much easier to denature. Because denatured proteins have distinct properties compared to the native forms, extreme care must be taken in protein microarrays. The fourth challenge is the availability of high quality antibodies. Antibodies are the most common capture agents in protein microarray technology. The need for high specificity, low cross-reactivity and high affinity are major hurdles in antibody development and production. The final challenge lies in the probing for each individual protein target. In striking contrast to the estimated 20,000 plus genes, the complexity of the human proteins is expected to range from 100,000 to several million. It still remains a distant dream to produce high quality antibodies to selectively recognize each of these different proteins.

\section{Successful Examples}

\section{Overview}

During the past several years, planar form antibody arrays have been applied in wide range of cancer research studies [4-6,23]. These fields include clinical trials to identify new cancer-specific markers for diagnosis and prognosis, pre-clinical studies using animal models and small-size samples, basic research on molecular mechanisms and pathways involved in cancer development and progression, and efficacy studies to find potential antitumor compounds/drugs. In this review, we will summarize the reported studies on cancer biomarker discovery using antibody arrays based on the cancer types studied.

\section{Ovarian cancer}

Ovarian cancer represents the third most frequent cancer and is one of the leading causes of cancer death among females in the United States and Europe [2]. Due to lack of typical symptoms, almost $80 \%$ of ovarian cancer patients are diagnosed at later stages. Unfortunately, the 5 -year survival rate for patients with clinically advanced ovarian cancer is only $15 \%$ to $20 \%$, in striking contrast to over $90 \%$ of 5 -year survival rate for patients with stage I disease [2]. These statistics motivate the discovery and development of ovarian cancer screening and early detection. Therefore, it is of utmost importance to discover and develop biomarkers for ovarian cancer screening and early detection. Currently, CA-125 and imaging are 2 most common approaches for ovarian cancer screening tests. However, with a cutoff of 30 to $35 \mathrm{IU} / \mathrm{ml}$, serum CA-125 has been shown to have a specificity of only $50 \%$ to $60 \%$ with the sensitivity of $>98 \%$ for early-stage disease. Multiple studies have reported the identification of cancer biomarkers using multiplex antibody array technology. Using human biotin label-based antibody arrays, we screened the serum expression profiles of 507 proteins in serum samples from 47 patients with ovarian cancers, 33 patients with benign ovarian masses and 39 healthy, age-matched controls. A panel of protein expression showed significant difference between normal and cancer $(P<0.05)$. By Classification Analysis and Split-Point 
Citation: Jiang W, Huang RP (2012) Overcoming the Deficiency of Singular Detection by Antibody Arrays in Cancer Biomarker Discovery. J Mol Biomark Diagn 3:132. doi:10.4172/2155-9929.1000132

Page 4 of 7

\begin{tabular}{|c|c|c|c|c|c|c|c|}
\hline Disease & Platform & Product name & Biomarker & Significant finding & $\begin{array}{l}\text { Sample } \\
\text { type }\end{array}$ & Sampel size & Reference \\
\hline $\begin{array}{l}\text { Ovarian } \\
\text { Cancer }\end{array}$ & $\begin{array}{l}\text { Glass slides-label } \\
\text { based antibody } \\
\text { array }\end{array}$ & $\begin{array}{l}\text { RayBiotech } \\
\text { L-507 }\end{array}$ & $\begin{array}{l}\text { Screening } \\
\text { marker }\end{array}$ & $\begin{array}{l}\text { Five proteins, including IL-2 receptor alpha, } \\
\text { endothelin, osteprotegerin, vascular endothelial } \\
\text { growth factor D (VEGF-D) and betacellulin } \\
\text { (BTC) were identified to distinguish ovarian } \\
\text { cancer from healthy controls. }\end{array}$ & Serum & $\begin{array}{l}\text { serum samples from } 47 \\
\text { patients with ovarian } \\
\text { cancers, } 33 \text { patients with } \\
\text { benign ovarian masses } \\
\text { and } 39 \text { healthy, age- } \\
\text { matched controls }\end{array}$ & (15) \\
\hline $\begin{array}{l}\text { Breast } \\
\text { Cancer }\end{array}$ & $\begin{array}{l}\text { Nitrocellulose } \\
\text { membranes- } \\
\text { sandwitch-based } \\
\text { antibody array }\end{array}$ & $\begin{array}{l}\text { RayBiotech } \\
\text { Human } \\
\text { Cytokine Array } \\
\text { III C-series }\end{array}$ & $\begin{array}{l}\text { pre-clinical } \\
\text { studies }\end{array}$ & $\begin{array}{l}44 \text { biomarkers were identified with increased } \\
\text { expression in MCF-7/Her2-18 cells (CXCL8, IL8, } \\
\text { CXCL1, and GRO) }\end{array}$ & $\begin{array}{l}\text { Cultural } \\
\text { Media }\end{array}$ & $\begin{array}{l}\text { Her-2 overexpressed cell } \\
\text { line MCF-7/Her2-18 and } \\
\text { parental cell line MCF-7/ } \\
\text { neo cell line }\end{array}$ & (27) \\
\hline $\begin{array}{l}\text { Breast } \\
\text { Cancer }\end{array}$ & $\begin{array}{l}\text { Glass slides- } \\
\text { label-based } \\
\text { antibody array }\end{array}$ & $\begin{array}{l}\text { In house } \\
\text { custom } \\
\text { production }\end{array}$ & $\begin{array}{l}\text { efficacy } \\
\text { markers }\end{array}$ & $\begin{array}{l}\text { A panel of } 4 \text { proteins (AP-2, catalase, } \\
\text { thymidylate synthase, and ErbB2) was higher in } \\
\text { MDA-MB- } 231 \text { cells compared with control cells }\end{array}$ & $\begin{array}{l}\text { Cell } \\
\text { Lysates }\end{array}$ & $\begin{array}{l}\text { THP cell line exposed } \\
\text { to different drug delivery } \\
\text { systems, including } \\
\text { amphotericin B (AMB), } \\
\text { Fungizone (FZ) and } \\
\text { Amphotec (ABCD), and } \\
\text { controls AmBisome } \\
\text { (L-AMB) or Abelcet } \\
\text { (ABLC) }\end{array}$ & (25) \\
\hline $\begin{array}{l}\text { Breast } \\
\text { Cancer }\end{array}$ & $\begin{array}{l}\text { Glass slides- } \\
\text { label-based } \\
\text { antibody array }\end{array}$ & $\begin{array}{l}\text { The BD } \\
\text { antibody } \\
\text { microarray } 380\end{array}$ & $\begin{array}{l}\text { pre-clinical } \\
\text { studies }\end{array}$ & $\begin{array}{l}\text { A panel of protein markers were identified to } \\
\text { distinguish malignant and adjacent normal } \\
\text { breast tissue in a patient with primary breast } \\
\text { cancer, including casein kinase le, p53, annexin } \\
\text { XI, CDC25C, elF-4E and MAP kinase } 7 \text { and } \\
14-3-3 e \text {. }\end{array}$ & $\begin{array}{l}\text { Tissue } \\
\text { Lysates }\end{array}$ & $\begin{array}{l}\text { Normal and malignant } \\
\text { breast tissue was } \\
\text { obtained from a 54-year- } \\
\text { old consenting post- } \\
\text { menopausal patient } \\
\text { undergoing modified } \\
\text { mastectomy for early } \\
\text { breast cancer }\end{array}$ & (24) \\
\hline $\begin{array}{l}\text { Breast } \\
\text { Cancer }\end{array}$ & $\begin{array}{l}\text { Glass slides- } \\
\text { label-based } \\
\text { antibody array }\end{array}$ & $\begin{array}{l}\text { In house } \\
\text { custom } \\
\text { production }\end{array}$ & $\begin{array}{l}\text { Prognosis } \\
\text { marker }\end{array}$ & $\begin{array}{l}\text { A panel of } 21 \text { protein markers were identified } \\
\text { to distingusih high-vs-low-risk groups for } \\
\text { development of distant metastatic breast } \\
\text { cancers }\end{array}$ & Serum & $\begin{array}{l}240 \text { sera samples from } \\
64 \text { primary breast cancer } \\
\text { patients, which were } \\
\text { collected at the primary } \\
\text { operation and then } 3-6 \\
\text { month later }\end{array}$ & (29) \\
\hline Brain Tumor & $\begin{array}{l}\text { Glass slides- } \\
\text { label-based } \\
\text { antibody array }\end{array}$ & $\begin{array}{l}\text { In house } \\
\text { custom } \\
\text { production }\end{array}$ & $\begin{array}{l}\text { Prognosis } \\
\text { marker }\end{array}$ & $\begin{array}{l}\text { A 15-marker panel was identified to } \\
\text { classification of GBM patients into long-term } \\
\text { survival vs short-term survival group }\end{array}$ & Serum & $\begin{array}{l}\text { serum samples from } \\
18 \mathrm{GM} \text { patients and } 17 \\
\text { healthy controls }\end{array}$ & (32) \\
\hline $\begin{array}{l}\text { Colorectal } \\
\text { Cancer( } \\
\text { CRC ) }\end{array}$ & $\begin{array}{l}\text { Glass slides- } \\
\text { label-based } \\
\text { antibody array }\end{array}$ & $\begin{array}{l}\text { RayBiotech } \\
\text { L-507 }\end{array}$ & $\begin{array}{l}\text { treatment } \\
\text { monitoring } \\
\text { marker }\end{array}$ & $\begin{array}{l}58 \text { and } 47 \text { proteins identified with significant } \\
\text { modulation at post vaccination of month } 2 \text { and } \\
4, \text { compared with prevaccination }\end{array}$ & plasma & $\begin{array}{l}14 \text { samples from } \\
18 \text { patients with } \\
\text { prevaccination, post } \\
\text { vaccination month } 2 \text { and } \\
\text { month } 4\end{array}$ & (31) \\
\hline $\begin{array}{l}\text { Prostate } \\
\text { Cancer }\end{array}$ & $\begin{array}{l}\text { Nitrocellulose } \\
\text { membranes- } \\
\text { sandwitch-based } \\
\text { antibody array }\end{array}$ & $\begin{array}{l}\text { RayBiotech } \\
\text { Human } \\
\text { Cytokine } \\
\text { ArrayC-series } \\
2000\end{array}$ & $\begin{array}{l}\text { pre-clinical } \\
\text { studies }\end{array}$ & $\begin{array}{l}\text { MCP-1 and IL-8 was highly expressed in all } \\
\text { prostate cancer cell lines compared with control } \\
\text { cell line. In addition, Levels of GRO-alpha } \\
\text { were greater in LNCaP, C4-2B and PC3 cells } \\
\text { compared with PrEC cells, Levels of VEGF, } \\
\text { CXCL-16 and MMP-9 were greater in PC } 3 \text { cells } \\
\text { compared with PrEC cells }\end{array}$ & $\begin{array}{l}\text { Cultural } \\
\text { Media }\end{array}$ & $\begin{array}{l}4 \text { different prosate cancer } \\
\text { cell lines ( LNCaP, C4-2B, } \\
\text { PC3, A549) and prostate } \\
\text { cell line PrEC. }\end{array}$ & (30) \\
\hline $\begin{array}{l}\text { Bladder } \\
\text { Cancer }\end{array}$ & $\begin{array}{l}\text { Glass slides-RCA } \\
\text { antibody array }\end{array}$ & $\begin{array}{l}\text { In house } \\
\text { custom } \\
\text { production }\end{array}$ & $\begin{array}{l}\text { screening } \\
\text { marker }\end{array}$ & $\begin{array}{l}\text { Serum protein profiles measured by an antibody } \\
\text { array containing } 254 \text { antibodies discriminated } \\
\text { bladder cancer patients from controls }(n-95) \\
\text { with a correct classification rate of } 93.7 \% \text {. A } \\
\text { second independent antibody array containing } \\
144 \text { antibodies revealed that protein profiles } \\
\text { provide predictive information by stratifying } \\
\text { patients with bladder tumors }\left(n \_37\right) \text { based on } \\
\text { their overall survival }(P<0.05)\end{array}$ & Serum & $\begin{array}{l}\text { SerumSerum samples } \\
\text { from } 95 \text { individuals } \\
\text { representing } 58 \text { controls } \\
\text { and } 37 \text { patients with } \\
\text { bladder cancer }\end{array}$ & (34) \\
\hline $\begin{array}{l}\text { Pancreatic } \\
\text { Cancer }\end{array}$ & $\begin{array}{l}\text { Glass slides-RCA } \\
\text { antibody array }\end{array}$ & $\begin{array}{l}\text { In house } \\
\text { custom } \\
\text { production }\end{array}$ & $\begin{array}{l}\text { screening } \\
\text { marker }\end{array}$ & & Serum & $\begin{array}{l}\text { One hundred forty- } \\
\text { two serum samples } \\
\text { were used from three } \\
\text { classes: healthy subjects } \\
(\mathrm{n}=50) \text {, pancreatic } \\
\text { adenocarcinoma patients } \\
(\mathrm{n}=61) \text {, and patients } \\
\text { with benign pancreatic } \\
\text { diseases }(\mathrm{n}=31)\end{array}$ & (37) \\
\hline $\begin{array}{l}\text { Pancreatic } \\
\text { Cancer }\end{array}$ & $\begin{array}{l}\text { Glass slides- } \\
\text { label-based } \\
\text { antibody array }\end{array}$ & $\begin{array}{l}\text { In house } \\
\text { custom } \\
\text { production }\end{array}$ & $\begin{array}{l}\text { screening and } \\
\text { prognosis } \\
\text { marker }\end{array}$ & & Serum & $\begin{array}{l}\text { serum samples from } 24 \\
\text { pancreatic cancer patients } \\
\text { and } 20 \text { healthy controls }\end{array}$ & (33) \\
\hline
\end{tabular}




\begin{tabular}{|c|c|c|c|c|c|c|}
\hline Leaukemia & $\begin{array}{l}\text { Nitrocellulose } \\
\text { membranes- } \\
\text { sandwitch-based } \\
\text { antibody array }\end{array}$ & $\begin{array}{l}\text { RayBiotech } \\
\text { Human } \\
\text { Cytokine Array }\end{array}$ & $\begin{array}{l}\text { efficacy } \\
\text { markers }\end{array}$ & $\begin{array}{l}\text { Culture } \\
\text { Media }\end{array}$ & $\begin{array}{l}\text { THP cell line exposed } \\
\text { to different drug delivery } \\
\text { systems, including } \\
\text { amphotericin B (AMB), } \\
\text { Fungizone (FZ) and } \\
\text { Amphotec (ABCD), and } \\
\text { controls AmBisome } \\
\text { (L-AMB) or Abelcet } \\
\text { (ABLC) }\end{array}$ & (36) \\
\hline
\end{tabular}

Table 1: Summary of cancer-related biomarker discoveries using planar form of antibody arrays.

Score Analysis of these two groups, a 6-marker panel of proteins (IL-2 receptor alpha, endothelin, osteprotegerin, vascular endothelial growth factor D (VEGF-D) and betacellulin (BTC)) can be used to distinguish ovarian cancer patients from normal subjects. These studies strongly suggest that antibody array technology has shown great promise in the discovery and development of ovarian cancer biomarkers [15].

\section{Breast cancer}

Breast cancer represents the leading cancer in incidence and second deadly cancer in female in US [24]. Due to the heterogeneity of breast cancer, the search for multi-marker panels enabling more accurate and reliable diagnosis, prognosis and treatment monitoring has drawn more attention. Antibody array technology has been used to identify such multi-marker signatures by many groups.

Yeretssian et al. identified unique expression profiling of proteins in breast-cancer derived cell lines [25]. Hudelist et al. identified a group of biomarkers by comparing protein expression in malignant and adjacent normal breast tissue from the same cancer patients [26]. Antibody arrays were also used to identify biomarkers for monitoring treatment response. Vazques-Martin et al. reported the identification of a HER-2 induced "cytokine signature" in breast cancer. Using a human cytokine antibody array, a 42 cytokine and growth factor expression profile was compared in conditioned media from MCF7/Her2-18 cells and MCF-7/Neo control cells. Four biomarkers were identified with increased expression in MCF-7/Her2-18 cells (CXCL8, IL-8, CXCL1, and GRO). The findings may represent novel biomarkers in monitoring breast cancer responses to endocrine treatments and/or HER-2-targeted therapy [27]. Smith et al. identified 5 proteins (cyclin D1,2, cytokeratin 18, cyclin B1, hnRNPm3-m4 and ERK) for potential markers to monitoring doxorubicin resistance [28].

Most recently, Carlsson et al. reported a potential signature protein panel to predict the development of distant metastasis in breast cancer [29]. Using a recombinant antibody array platform containing 135 antibodies against 65 protein markers, Borrebaeck's group screened 240 sera samples from 64 primary breast cancer patients, which were collected at the primary operation and then 3-6 month later. They identified a 21-marker panel using leave-one-out cross-validation coupled with backward elimination strategy. This 21-marker signature was then evaluated and validated in a separate independent cohort samples. The results showed that patients could be classified into high-vs-low-risk groups for development of distant metastatic breast cancer with an AUC of 0.85 by receiver operating characteristic [29]. Those studies strongly suggest that planar antibody array technology has shown great promise in the discovery and development of breast cancer biomarkers.

\section{Prostate cancer}

Prostate cancer is the most common cancer and also has the second highest mortality rate in U.S. About 70 to $80 \%$ of metastasis from prostate cancer is in the bone. Strategies to inhibit prostate cancer metastasis include targeting both tumor-induced osteoblastic lesions and underlying osteoclastic activities. In order to identify biomarkers which mediate cancer-induced osteoclastic activity, antibody arrays were used to identify biomarkers for monitoring treatment response activities. Lu et al. measured cytokine expression profiles in conditioned media from primary prostate epithelial cells, prostate cancer LNCaP and its derivative C4-2B and PC 3 cells. A panel of cytokine markers was identified with increased expression in cancer and cancer-derived cells (MCP-1, IL-6, IL-8, GRO-alpha, ENA-78, XCXL16). The results may provide novel therapeutic targets for treatment of prostate-induced bone metastasis [30].

\section{Colorectal cancer}

In order to find biomarkers for monitoring cancer vaccine efficacy, Toh et al. performed expression profiling of 507 proteins using a biotin label-based antibody array in prevaccination and postvaccination (month 2 and month 4) samples. 58 and 47 proteins were identified when comparing samples from postvaccination month 2 and 4 with prevaccination, respectively. Among them, 28 proteins showed consistent increased expression in both time points of postvaccination. Furthermore, using a customized quantitative antibody array, a panel of 4 proteins were identified to be used as markers to distinguish vaccine responders from non-responders (CXCL11, L-selectin, MCP-1 and soluble gp130). The results may point to a novel way of monitoring vaccine treatment efficacy in appropriate cancer patients [31].

\section{Brain tumor}

Glioblastoma Multiforme (GBM) is the most common type as well as the most aggressive type of primary brain tumor in the United States. The prognosis for glioblastoma multiforme is very poor. Even with surgery with combination of radiotherapy and chemotherapy, the median survival is less than 15 months. Recently immunotherapy has shed light on GBM treatment. However, due to varying efficiency among treated cancer patients, along with the heterogeneity of the etiology of GBM, there is clearly a great need for developing tailored, personalized treatment regimens. Carlsson et al. reported a potential signature protein panel to predict the prognosis and therapy selection in GBM patients. Using a novel recombinant antibody array platform containing 135 antibodies against 65 protein markers, they screened sera from 18 primary GBM patients and 17 healthy controls. They identified a 15-marker panel using leave-one-out cross-validation coupled with Support Vector Machine analysis to classification of GBM patients into long-term survival vs short-term survival group with an AUC of 0.79-0.91 by receiver operating characteristic [32]. Those studies strongly suggest that planar antibody array technology has shown great promise in the prognosis and treatment guidance of glioma patients.

\section{Pancreatic cancer}

Pancreatic cancers are among the most deadly cancers, accounting for more than 3000 deaths annually in the United States. The 5-year 
survival stands dissapointly at 3 to $5 \%$. The high mortality rate is mainly due to lack of early diagnosis combined with ineffective available treatments for advanced stages of pancreatic cancers. There is clearly a great need for biomarker signatures for early detection for pancreatic cancer patients. Ingvarsson et al. identified a 19-marker panel to distinguish pancreatic cancer patients from healthy controls using a recombinant antibody array platform. Furthermore, a panel of 21 markers could be used to predict cancer patients with a life expectancy of less than 1 year. Those studies strongly suggest that planar antibody array technology has shown great promise in detection and prediction of pancreatic cancer patients [33].

\section{Other cancers}

Multiple groups have used antibody array technology for discovery of biomarkers for other cancer types. Due to the limitation of the scope of this review, only references have been listed. These cancers include bladder cancer, leukemia, and other cancers [34-36].

\section{Conclusions}

Antibody array technology has shown promise in the discovery and development of cancer biomarkers. These various antibody array platforms have the advantage of being high-throughput, multiplexed, quantitative, fast, cost-effective, and having microliter-volume sample requirements. Though major challenges in antibody array technology still exist, improvements in new detection amplification methods, enhanced sample concentration methodology, availability of more highly specific antibodies in the commercial market, this technology will not only be used for protein expression profiling, but also for pathway analysis, drug discovery and molecular classification of cancers.

\section{Acknowledgement}

We thank Dr. Valerie Jones and Dr. Brett Burkholder for constructive discussion. This work was supported by NIH/NCI grant 1R41HD065360-01 (RPH). We would like to express our thanks for the support by leading scientist project for Guangzhou economic development district (2009L-P180), Guangzhou leading talent entrepreneurial venture, (LCY 201111) Guangdong innovative research team program (20100150104659419) and research grant from Guangzhou economic development district (2010Q-P450)

\section{References}

1. Pepe MS, Etzioni R, Feng Z, Potter JD, Thompson ML, et al. (2001) Phases of biomarker development for early detection of cancer. J Natl Cancer Inst 93 : 1054-1061.

2. Zolg JW, Langen $\mathrm{H}$ (2004) How industry is approaching the search for new diagnostic markers and biomarkers. Mol Cell Proteomics 3: 345-354.

3. Kozak KR, Amneus MW, Pusey SM, Su F, Luong MN, et al. (2003) Identification of biomarkers for ovarian cancer using strong anion-exchange ProteinChips: potential use in diagnosis and prognosis. Proc Natl Acad Sci U S A 100: 1234312348.

4. Huang RP (2007) An array of possibilities in cancer research using cytokine antibody arrays. Expert Rev Proteomics 4: 299-308.

5. Sanchez-Carboyo M (2010) Antibody array-based technologies for cance protein profiling and functional proteomic analysis using serum and tissue specimens. Tumor Biol 31: 103-112.

6. Kopf E, Zharhary D (2007) Antibody arrays-an emerging tool in cancer proteomics. Int J Biochem Cell Biol 39: 1305-1317.

7. Huang RP (2004) Cytokine protein arrays. Methods Mol Biol 264: 215-231.

8. Borrebaeck CA, Wingren C (2007) High-throughput proteomics using antibody microarrays: an update. Expert Rev Mol Diagn 7: 673-686.

9. Borrebaeck CA, Wingren C (2009) Design of high-density antibody microarrays for disease proteomics: key technological issues. J Proteomics 72: 928-935.

10. Knight PR, Sreekumar A, Siddiqui J, Laxman B, Copeland S, et al. (2004)
Development of a sensitive microarray immunoassay and comparison with standard enzyme-linked immunoassay for cytokine analysis. Shock 21: 26-30.

11. Moody MD, Van Arsdell SW, Murphy KP, Orencole SF, Burns C (2001) Arraybased ELISAs for high-throughput analysis of human cytokines. Biotechniques 31: 186-194.

12. Hsu HY, Wittemann S, Joos TO (2008) Miniaturized Parallelized Sandwich Immunoassays. Methods in Molecular Biology 428, 247-261.

13. Kingsmore SF (2006) Multiplexed protein measurement: technologies and applications of protein and antibody arrays. Nat Rev Drug Discov 5: 310-320.

14. Lin Y, Huang R, Chen L, Li S, Shi Q, et al. (2004) Identification of interleukin-8 as estrogen receptor-regulated factor involved in breast cancer invasion and angiogenesis by protein arrays. Int J Cancer 109: 507-515.

15. Huang R, Jiang W, Yang J, Mao YQ, Zhang Y, et al. (2010) A biotin labelbased antibody array for high-content profiling of protein expression. Cancer Genomics Proteomics 7: 129-141.

16. Schweitzer B, Roberts S, Grimwade B, Shao W, Wang M, et al. (2002) Multiplexed protein profiling on microarrays by rolling-circle amplification. Nat Biotechol 20: 359-365

17. Spisak S, Tulassay Z, Molnar B, Guttman A (2007) Protein microchips in biomedicine and biomarker discovery. Electrophoresis 28: 4261-4273.

18. Chandra H, Reddy PJ, Srivastava S (2011) Protein microarrays and novel detection platforms. Expert Rev Proteomics 8: 61-79.

19. Kusnezow W, Banzon V, Schroder C, Schaal R, Hoheisel JD, et al. (2007) Antibody microarray-based profiling of complex specimens: systematic evaluation of labeling strategies. Proteomics 7: 1786-1799.

20. Ray S, Mehta G, Srivastava S (2010) Label-free detection techniques for protein microarrays: prospects, merits and challenges. Proteomics 10: 731-748.

21. Ladd J, Taylor AD, Piliarik M, Homola J, Jiang S (2009) Label-free detection of cancer biomarker candidates using surface plasmon resonance imaging. Anal Bioanal Chem 393: 1157-1163.

22. Boozer C, Kim G, Cong S, Guan H, Londergan T (2006) Looking towards labelfree biomolecular interaction analysis in a high-throughput format: a review of new surface plasmon resonance technologies. Curr Opin Biotechnol 17: 400405

23. Haab BB (2005) Antibody arrays in cancer research. Mol Cell Proteomics 4 377-383.

24. Jemal A, Siegel R, Xu J, Ward E (2010) Cancer statistics, 2010. CA Cancer J Clin 60: 277-300.

25. Yeretssian G, Lecocq M, Lebon G, Hurst HC, Sakanyan V (2005) Competition on nitrocellulose-immobilized antibody arrays: from bacterial protein binding assay to protein profiling in breast cancer cells. Mol Cell Proteomics 4: 605-617.

26. Hudelist G, Pacher-Zavisin M, Singer CF, Holper T, Kubista E, et al. (2004) Use of high-throughput protein array for profiling of differentially expressed proteins in normal and malignant breast tissue. Breast Cancer Res Treat 86: 281-291.

27. Vazquez-Martin A, Colomera R, Menendeza JA (2007) Protein array technology to detect HER2 (erbB-2)-induced 'cytokine signature' in breast cancer. Eur J Cancer 43: 1117-1124.

28. Smith L, Watson MB, O'Kane SL, Drew PJ, Lind MJ, et al. (2006) The analysis of doxorubicin resistance in human breast cancer cells using antibody microarrays. Mol Cancer Ther 5: 2115-2120.

29. Carlsson A, Wingren C, Kristensson M, Rose C, Ferno M, et al. (2011) Molecular serum portraits in patients with primary breast cancer predict the development of distant metastases. Proc Natl Acad Sci U S A 108: 14252-14257.

30. Lu Y, Cai Z, Xiao G, Keller ET, Mizokami A, et al. (2007) Monocyte Chemotactic Protein-1 Mediates Prostate Cancer-Induced Bone Resorption. Cancer Res 67: 3646-3653

31. Toh HC, Wang WW, Chia WK, Kvistborg P, Sun L, et al. (2009) Clinical Benefit of Allogeneic Melanoma Cell Lysate-Pulsed Autologous Dendritic Cell Vaccine in MAGE-Positive Colorectal Cancer Patients. Clin Cancer Res 15: 7726-7736.

32. Carlsson A, Persson O, Ingvarsson J, Widegren B, Salford L, et al. (2010) Plasma proteome profiling reveals biomarker patterns associated with prognosis and therapy selection in glioblastoma multiforme patients. Proteomics Clin Appl 4: 591-602. 
Citation: Jiang W, Huang RP (2012) Overcoming the Deficiency of Singular Detection by Antibody Arrays in Cancer Biomarker Discovery. J Mol Biomark Diagn 3:132. doi:10.4172/2155-9929.1000132

Page 7 of 7

33. Ingvarsson J, Wingren C, Carlsson A, Ellmark P, Wahren B, et al. (2008) Detection of pancreatic cancer using antibody microarray-based serum protein profiling. Proteomics 8: 2211-2219.

34. Sanchez-Carbayo M, Socci ND, Lozano JJ, Haab BB, Cordon-Cardo C (2006) Profiling bladder cancer using targeted antibody arrays. Am J Pathol 168: 93103

35. Celis JE, Gromova I, Moreira JM, Cabezon T, Gromov P (2004) Impact of proteomics on bladder cancer research. Pharmacogenomics 5: 381-394.
36. Turtinen LW, Prall DN, Bremer LA, Nauss RE, Hartsel SC (2004) Antibody array-generated profiles of cytokine release from THP-1 leukemic monocytes exposed to different amphotericin B formulations. Antimicrob Agents Chemother 48: 396-403.

37. Orchekowski R, Hamelinck D, Li L, Gliwa E, VanBrocklin M, et al. (2005) Antibody microarray profiling reveals individual and combined serum proteins associated with pancreatic cancer. Cancer Res 65: 11193-11202. 